\title{
Humoral responses of broiler chickens challenged with NDV following supplemental treatment with extracts of Aloe vera, Alma millsoni, Ganoderma lucidum and Archachatina marginata
}

\author{
TONY I. OJIEZEH', NOSAHKARE'ODEH EGHAFONA ${ }^{2}$ \\ ${ }^{1}$ Afe Babalola University, Ado Ekiti, Ekiti State, Nigeria \\ ${ }^{2}$ University of Benin, Benin City, Edo State, Nigeria
}

\begin{abstract}
Aim of the study: The significance of nutritional supplements for immunity has been documented. Locally sourced extracts used in alternative medicine were studied to determine their potential effects on antibody production and humoral responses in viral challenged birds.

Method: Three hundred and eighty birds were distributed into 19 groups of 20 birds each. Following acclimatization for 16 days, they were fed with standard broilers feed and water ad libitum. Group A was supplemented with Aloe vera (AV) extract, group B was given Alma millsoni (AM) extract, group $C$ was given Archachatina marginata (AMS) extract and group $D$ was given Ganoderma lucidum (GL) extract, and group E was the control group. Extract concentrations of $50 \mathrm{mg}, 100 \mathrm{mg}$ and $150 \mathrm{mg}$ were given to three subsets of each treatment group for 30 days. Birds were then challenged with intramuscular administration of $0.2 \mathrm{ml}$ of 50\% Embryo Lethal Dose of saline suspension of the challenge strain of Newcastle Disease Virus (NDV) on the $30^{\text {th }}$ day, and were examined for clinical signs and symptoms. Serum from venous blood was used for antibody and immunological assay.

Results: Aloe vera at $50 \mu \mathrm{g}$ and A. millsoni extracts supplementations yielded a significant antibody titre $(p<0.001)$. The difference within the AMS, GL and AV groups and the control group was not statistically significant $(p<0.05)$.

Conclusion: Unlike the extract of Ganoderma and A. marginata, pretreatment with A. millsoni extract and a lower dosage of Aloe vera enhanced the ability to mount humoral responses against viral infection in broiler chickens.
\end{abstract}

Key words: $N D V$, supplementation, broilers, extracts, antibody responses.

(Cent Eur J Immunol 2015; 40 (3): 300-306)

\section{Introduction}

Immunity is the ability of a host to resist invading pathogens and prevent them from colonizing and multiplying in the system. The avian immune system is categorized into non-specific and specific immune mechanisms. Non-specific immune mechanisms include the innate or inherent ways in which the chicken resists disease [1]. These protective systems tend to rely primarily on vaccinations and/or antibiotics to maintain flock health [1]. Though, the importance of the non-specific immune mechanism has been well documented. Body temperature, anatomic features, normal microflora on the skin and gut normally maintain a dense stable microbial population and respiratory tract cilia and part of the respiratory system are lined with cilia which remove organisms and debris [1]. Other factors involved in innate resistance include nutrition, environment (avoid heat/cold stress), age (young/old animals are more susceptible to disease), inflammation processes, metabolic factors, complement, and interferon. Poor nutrition may lead to deficiencies which allow organisms to penetrate the protective body coverings [1].

The important role of nutrients as regulators of the immune system was first recognized in the early $1800 \mathrm{~s}$ [2]. The nutritional and physicochemical profiles of the extracts have been documented [3]. Antioxidant nutrients

Correspondence: Tony I. Ojiezeh, Department of Medical Lbaoratory Science, College of Medicine and Health Sciences, 361001 Ado Ekiti, Nigeria, e-mail: pastortksm@gmail.com 
such as vitamin $\mathrm{E}$ and selenium as well as micronutrients such as Vitamins A, D, and zinc, and fatty acids, have shown to regulate developmental processes as well as the functions of various cells of the immune system. Several meetings and symposia have broadly reviewed the effects of numerous nutrients on the immune function [4]. Regulation of numerous immune responses may be achieved through nutrient influences on signal transduction and expression of critical immunoregulatory genes [4].

Antibodies serve various functions in protecting the host against the pathogen. Their soluble forms which carry out these functions are produced by plasma B-cells, a type of white blood cells. This production is tightly regulated and requires the activation of B-cells by activated T-cells (another type of white blood cells), which is a sequential procedure [5]. According to Radoja et al. [6], the major steps involved are recognition of pathogens, antigen processing, antigen presentation, T-cell stimulation, proliferation and differentiation of B- cell, and clonality of B-cells. Vahedi et al. [7] noted that activation of the innate immune cells (macrophages, neutrophils, lymphocytes and natural killer cells) stimulate the synthesis and release of cytokines (TNF- $\alpha$, IFN- $\alpha$, IFN- $\gamma$, IL-1, IL-2, IL-6 and IL-8), generation of enhanced cell mediated responses, and induction of nitric oxide production [8-11].

\section{Material and methods}

\section{Laboratory animals (broilers)}

The experimental animals comprised of 380-day-old broilers obtained from Obasanjo Hatchery, Oluyole Estate, Ibadan, Oyo State. They were transported to the Animal House, Achievers University, Owo, Ondo State, Nigeria.

\section{Innocula}

A vial of a lyophilized challenged strain of Newcastle disease virus (NDV) was obtained from the Regional Laboratory for Avian Influenza and Tran boundary Animal Diseases, National Veterinary Research Institute, Vom. The vial was transported under cold chain and standard bio-safety practice to Owo, Ondo State. A saline suspension of $10^{6} \mathrm{ELD}_{50}$ was prepared by taking up the vial in $1.5 \mathrm{ml}$ of sterile diluents (physiological saline), then take $1 \mathrm{ml}$ of the reconstituted virus to add $99.0 \mathrm{ml}$ sterile normal saline.

\section{Alma millsoni (ALM) extract}

Samples of Alma millsoni were sourced from riverside of Okitipupa, Ondo State, washed with rain water and transported in a clean plastic bucket with sand and water to the laboratory for processing. Samples identified and authenticated were deposited in the Biological Science Laboratory, Achievers University, Owo. The extraction of
A. millsoni tonic from the worms was carried out according to the method described by Ang Lopez and Raelm [12].

\section{Aloe vera (AV) extract}

Samples of the succulent leaves of the aloe plant were harvested and washed with distilled water. Samples identified and authenticated were deposited in the Biological Science Department, Achievers University, Owo. The Aloe vera juice was prepared following the method described by $\mathrm{Wu}$ et al. [13] with a slight modification. In brief the modification included the following steps: freshly harvested leaves of the plant were washed, drained and cut open. The inner pulp was scrapped into a clean beaker and warmed at $50^{\circ} \mathrm{C}$ for $30 \mathrm{~min}$. until the viscous light yellow pulp became less viscous. The extract was filtered with a muslin cloth.

\section{Ganoderma lucidum (GL) extract}

The fungi body of G. lucidum was obtained locally from open forest at Ipele in Ose Local Government Area of Ondo State, Nigeria. The fungal material identified and authenticated was deposited in the Department of Biological Sciences, Joseph Ayo Babalola University, Ikeji-Arakeji, Osun State, Nigeria. The Ganoderma extract was prepared using the aqueous extraction method as described by Oluba et al. [14].

\section{Archachatina marginata (AM) extract}

The homemade giant land snails were transported to the laboratory for processing. Samples were identified and authenticated in the Biological Science Laboratory, Achievers University, Owo. The snails were washed thoroughly and rinsed with distilled water. With the aid of giant forceps, the shells were carefully cracked to access the sexual apparatus and tapped out juice/fluid from the albumin gland into the beaker. The fluid was then centrifuged at $5000 \mathrm{rpm}$ for $10 \mathrm{~min}$. thereby yielding supernatant, precipitated and gelatinous sludge. The bluish supernatant was carefully extracted into a conical flask and stored at $4{ }^{\circ} \mathrm{C}$ till required.

\section{Preparation of extracts}

The extracts of AV, ALM, AM and GL were evaporated to dryness at $37^{\circ} \mathrm{C}$ using a Speed Vac (Model 7811001, Labconco, USA). The recovered extract was weighed and formulated in distilled water to give the required dose.

\section{Treatment of broilers}

During the entire study, the broilers were fed with feeds compounded carefully to meet $23 \%$ crude protein (CP) and $3200 \mathrm{kcal}$, metabolizable energy (ME) for broiler starter and $20 \% \mathrm{CP}$ and $3000 \mathrm{kcal}$. for broiler finisher. We ensured that the levels of mycotoxins in feed were 
maintained relatively low throughout the experiment, the quality and quantities of groundnut cake (GNC), soya bean and rice bran included in the feeds were the same for both starter and finisher mash. The percentage CP in feed and ingredients were determined by the biurette method [15] while the metabolizable energy was determined by the Bomb calorimeter method [16]. The broilers were housed in battery cages of $0.31 \mathrm{~m}^{2} /$ bird as recommended by Mustafa et al. [17]. All experimental protocols complied with NIH guidelines [18]. The research protocol was approved by the ethical and research committee, Achievers University, Owo. All the birds received necessary medication and vaccination exempting NDV vaccine with the exception of the NDV vaccinated control group. The birds were divided into 19 groups of 20 birds each; they were allowed to acclimatize for 16 days and were fed with standard broilers feed and water ad libitum. Group A was supplemented with Aloe vera extract, group B was supplemented with Alma millsoni (earthworm) extract, group C was supplemented with Archachatina marginata (snail serum) and group D was supplemented with Ganoderma lucidum (Lingzhi) extract, and group E was used as a control group. Extract concentrations of $50 \mathrm{mg}, 100 \mathrm{mg}$ and $150 \mathrm{mg}$ were given to three subgroups of each treatment group for 30 days. Birds were then challenged with intramuscular administration of $0.2 \mathrm{ml}$ of $10^{6} \mathrm{ELD}_{50}$ (50 percent Embryo Lethal Dose) of saline suspension of NDV on the $30^{\text {th }}$ day, and were examined for clinical signs and symptoms, and micro-flora of the trachea were specifically noted (though not reported in this paper).

\section{Blood sample collection}

A venous blood sample collected from the broilers' wings was delivered into EDTA bottle and plain bottles. The sample in the plain bottle was allowed to clot at room temperature of $28 \pm 1^{\circ} \mathrm{C}$ for $2 \mathrm{hr}$ and centrifuged at 2000 rpm for 10 min using a Gallenkamp bench centrifuge and the sera thus formed were then separated into sterile plain bottles and frozen at $4{ }^{\circ} \mathrm{C}$ until required for analysis. Blood films were prepared from the blood in the EDTA bottle and stained using Leishman's method as described by Lewis et al. [19]. Films were read according to the method described by Fudge [20].

\section{Immunological analysis}

Serum of each bird was separated and analyzed for the level of antibody titre using hemagglutination tests and hemagglutination-inhibition tests. Serum Immunoglobulins (IgY and IgM) were determined by ELISA technique (Microplate Reader ${ }^{\circledR}$ DAS) using a commercial kit of IgY and $\operatorname{IgM}\left(\mathrm{E}-30 \mathrm{Y}^{@}\right.$ and E-30M ${ }^{@}$ Immunology Consultant Laboratory, Inc., USA). The parameters were measured as a batch from each serum sample following methodology described by Clarke and Dufour [21].

\section{Statistical analysis}

Results presented are means \pm SEM of 5 values of individual birds per supplementation group. Data obtained from this study were statistically analyzed using one-way analysis of variance (ANOVA) and Duncan's Multiple Range Test (DMRT) using SPSS 17.0. Significant differences between the treatment means were determined at 95\% confidence level.

\section{Results}

The results in Table 1 show that the group supplemented with A. marginata serum and G. lucidum at concentrations used in this study yielded an insignificant antibody titre $(p>0.05)$, when compared with VNSNC group $4 \log _{2}$ $(\geq 4)$. The antibody raised by Aloe vera at $50 \mathrm{mg}$ was statistically significant $(p<0.001)$, but Aloe vera at a higher concentration of $100 \mathrm{mg}$ and $150 \mathrm{mg}$ had no effect on antibody stimulation in the birds. There was a significant antibody (titre) at a higher concentration of $A$. millsoni extract supplementation to the birds, the antibody titre was statistically significant $(p<0.001)$ and concentration dependent $(150 \mathrm{mg}>100 \mathrm{mg})$.

The frequency of plasma cells on the peripheral blood is shown in Table 2. Plasma cells were observed in the group supplemented with Aloe vera and A. millsoni extracts. It was also observed among the groups supplemented with $150 \mathrm{mg}$ of A. marginata and $150 \mathrm{mg}$ of G. lucidum. Plasma cells were not seen on the blood films of the control groups.

Table 1. Antibody titre $\left(\log _{2}\right)$ of Aloe vera, Alma millsoni extract, Ganoderma lucidum and Archachatina marginata serum supplemented broiler chickens after Newcastle Disease virus challenged and control group

\begin{tabular}{lccccccc}
\hline Supplementation groups (mg) & $\mathbf{0}$ & $\mathbf{5 0}$ & $\mathbf{1 0 0}$ & $\mathbf{1 5 0}$ & NSNC & SNC & VNSNC (control) \\
\hline Aloe vera & $\leq 4$ & $\geq 4$ & $\leq 4$ & $\leq 4$ & $\leq 4$ & $\geq 4$ & $\geq 4$ \\
\hline Alma millsoni & $\leq 4$ & $\leq 4$ & $\geq 4$ & $\geq 4$ & $\leq 4$ & $\leq 4$ & $\leq 4$ \\
\hline A. marginata & $\leq 4$ & $\leq 4$ & $\leq 4$ & $\leq 4$ & $\leq 4$ & $\leq 4$ & $\leq 4$ \\
\hline G. lucidum & $\leq 4$ & $\leq 4$ & $\leq 4$ & $\leq 4$ & $\geq 4$ \\
\hline
\end{tabular}

NDV antibody significant titre $=\geq 4\left(\log _{2}\right)$.

$N S N C$ - not supplemented not challenged; SNC - supplemented but not challenged; VNSNC-NDV vaccinated, not supplemented not challenged 
Table 2. Occurrence of plasma cell in peripheral blood of Aloe vera, Alma millsoni extract, Ganoderma lucidum and Archachatina marginata serum supplemented broiler chickens following Newcastle Disease virus challenged and control group

\begin{tabular}{|c|c|c|c|c|c|c|c|}
\hline Supplementation groups (mg) & $\mathbf{0}$ & $\mathbf{5 0}$ & 100 & 150 & NSNC & SNC & VNSNC (control) \\
\hline Aloe vera & - & + & + & + & - & - & - \\
\hline Alma millsoni & - & + & + & + & - & - & - \\
\hline A. marginata & - & - & - & + & - & - & - \\
\hline G. lucidum & - & - & - & + & - & - & - \\
\hline
\end{tabular}

Figures 1-4 show the correlation between Immunoglobulins $\mathrm{M}(\mu \mathrm{g} / \mathrm{ml})$ and $\mathrm{Y}(\mathrm{mg} / \mathrm{ml})$ of Aloe vera, A. millsoni extract, G. lucidum and A. marginata serum supplemented broiler chickens after NDV challenge and control groups. Levels of IgM among SC groups were low and not concentration dependent AV and AM $(150 \mathrm{mg}<100 \mathrm{mg}>50 \mathrm{mg})$ and GL ( $150 \mathrm{mg}<100 \mathrm{mg}>50 \mathrm{mg}$ ). The IgM was slightly raised in AMS and the moderation was concentration dependent $(150 \mathrm{mg}>100 \mathrm{mg}>50 \mathrm{mg}$ ) in test broilers. It was the least in NSC $(2.790 \pm 0.01)$, when compared with SNC $(2.830 \pm 0.10)$ and VNSNC $(3.008 \pm 0.01)$. In each group, the differences within SC and control was not statistically significant at $p<0.05$. Levels of IgY among SC groups in the various subgroups was low and concentration dependent in AV and AMS supplemented groups (150 mg > $100 \mathrm{mg}$ $>50 \mathrm{mg}$ ) but not concentration dependent in AM and GL groups $(150 \mathrm{mg}>100 \mathrm{mg}<50 \mathrm{mg}$ ). However, the IgY among test birds were observed to be raised when compared with the control VNSNC $(0.955 \pm 0.01)$ group. The difference between IgY within the SC groups and control group was statistically insignificant at $p>0.5$.

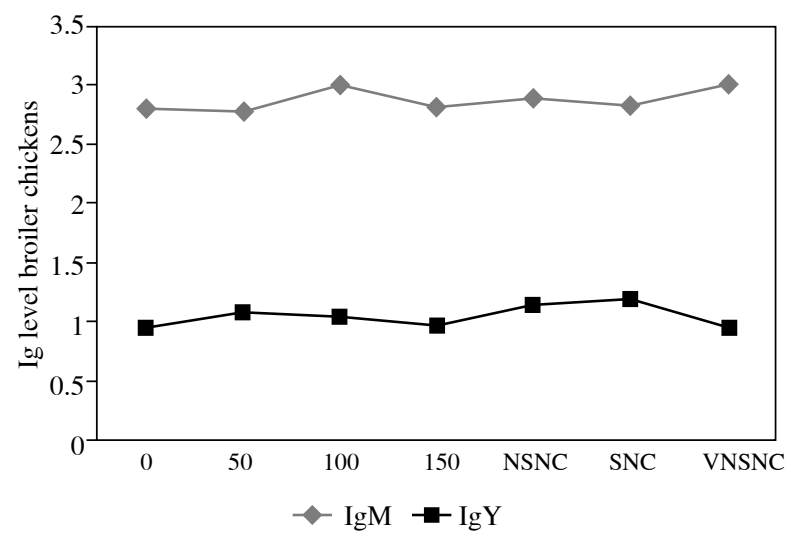

Mean \pm SEM, $p<0.05$ (significant at 0.05); NSNC - not supplemented not challenged; SNC-supplemented but not challenged; $V N S N C-N D V$ vaccinated not supplemented not challenged

Fig. 1. Correlation between $\operatorname{IgY}$ and IgM Aloe vera supplemented broiler chickens following NDV challenged and controls group

\section{Discussion}

Antigenic stimulation of Th- 1 cells induce T cell cytotoxicity and activation of macrophages that release cytokines like IL-2, IFN- $\gamma$ and TNF- $\beta$ and also in the stimulation of Th- 2 cells and production of B cells. Th- 2 cells plays a role in the stimulation of IL-4, IL-5, IL-10 and IL-13 cytokines leading to production of B cells and antibodies 43-45 [7]. The significant antibody titre in broilers supplemented with Aloe vera and A. millsoni extracts following the NDV challenge as demonstrated in this study, suggest that the duo extracts have potential to enhance antibody production against the NDV, thus, increase humoral response.

The presence of plasma cells in the peripheral blood of the broilers supplemented with AV and A. millsoni extracts further substantiate the fact that there was an infection and plasma cells production was increased as B-cell differentiate. The right shift in plasma cells production is usually followed by a gradual decrease in the number of circulating cells, and until it reaches a level sufficient to sustain the circulating antibodies. This finding is in agreement

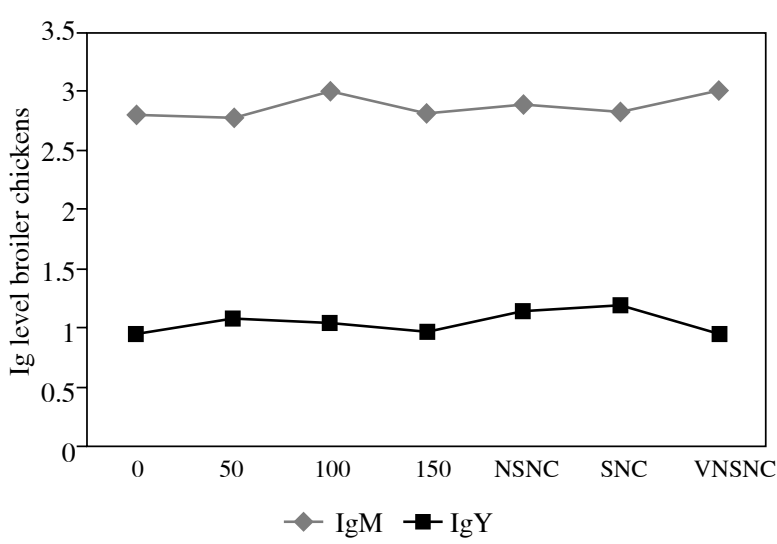

Mean \pm SEM, $p<0.05$ (significant at 0.05); NSNC-not supplemented not challenged; SNC - supplemented but not challenged; VNSNC NDV vaccinated not supplemented not challenged

Fig. 2. Correlation between IgY and IgM millsonic supplemented broiler chickens following NDV challenged and controls group 


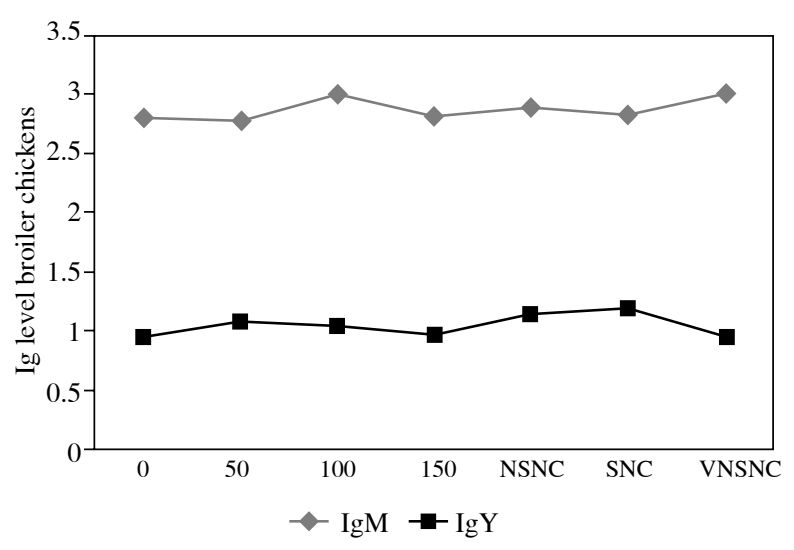

Mean \pm SEM, $p<0.05$ (significant at 0.05); NSNC-not supplemented not challenged; SNC - supplemented but not challenged; VNSNC$N D V$ vaccinated not supplemented not challenged

Fig. 3. Correlation between IgY and IgM Achachatina maginata supplemented broiler chickens following NDV challenged and controls group

with the report of other researchers $[8,10,22]$ who in their various report indicated that $A$. vera may stimulate humoral immune responses. Contrary to the reports of Ernst et al. [23] and Richardson et al. [24] who stated that systematic reviews of randomized and controlled clinical trials have provided no evidence that Aloe vera has a strong medicinal

Table 3. Gross composition of experimental diets for broiler chicken

\begin{tabular}{|c|c|c|}
\hline Ingredient & Starter diet (\%) & Finisher diet (\%) \\
\hline Maize & 55.00 & 55.00 \\
\hline *Groundnut cake (GNC) & 30.00 & 30.00 \\
\hline Soya bean meal & 9.10 & 5.00 \\
\hline Fish meal $(72 \%)$ & 2.00 & 1.50 \\
\hline Bone meal & 3.00 & 3.00 \\
\hline Common salt & 0.25 & 0.25 \\
\hline Lysine & 0.20 & 0.20 \\
\hline Methionine & 0.20 & 0.20 \\
\hline${ }^{* * *}$ Premix & 0.25 & 0.25 \\
\hline Wheat offal & - & 4.60 \\
\hline Crude protein $(\%)$ & 23 & 20 \\
\hline $\begin{array}{l}\text { Metabolizable energy } \\
(\mathrm{KJ} / \mathrm{kg})\end{array}$ & 3200 & 3000 \\
\hline \multicolumn{3}{|c|}{$\begin{array}{l}\text { *Contaminated GNC was used for the feed of the test birds, while high quality } \\
\text { GNC was used to prepare feed for the control birds. }\end{array}$} \\
\hline \multicolumn{3}{|c|}{ 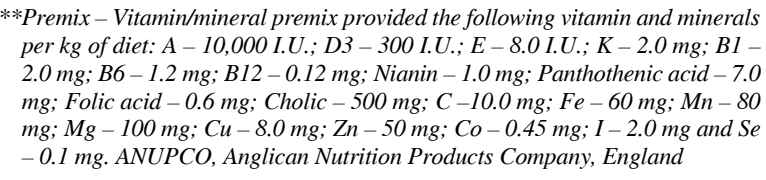 } \\
\hline
\end{tabular}

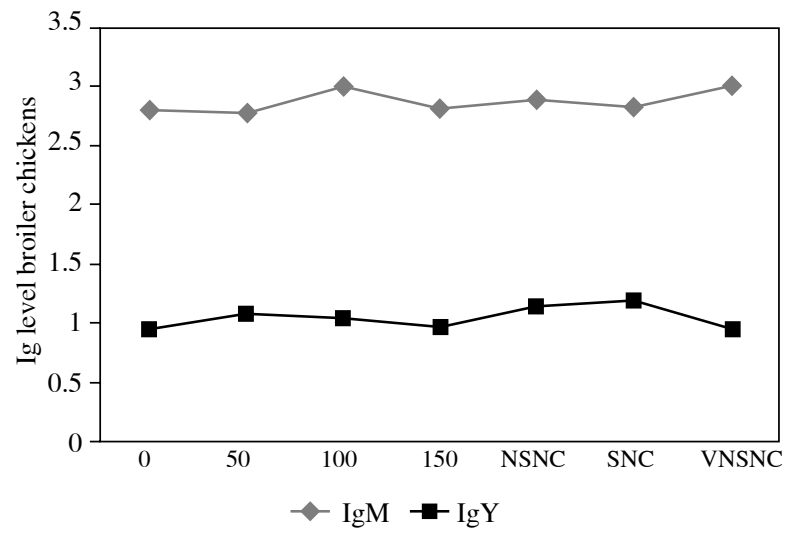

Mean \pm SEM, $p<0.05$ (significant at 0.05); NSNC-not supplemented not challenged; SNC - supplemented but not challenged; VNSNC NDV vaccinated not supplemented not challenged

Fig. 4. Correlation between IgY and IgM Ganoderma lucidum supplemented broiler chickens following NDV challenged and controls group

effect. Oral supplementation of Aloe vera and A. millsoni extract (tonic) in broiler chickens improved the potential to increase antibody response since the birds were not vaccinated with either Primer (NDV) or LaSota vaccines. Thus, when used as adjuvant it may have a multiplier effect in the host responses to infection. This finding is corroborated by the report of Yates et al. [25] and Chinnah et al. [26], which states that Aloe vera has the potential to increase antibody responses when used as adjuvant. And the earthworm has shown its anti-allergic, antioxidative, anticancer, antiulcer and anti-inflammatory activity [27, 28]. IgM antibodies are produced immediately after the exposure, while IgY antibodies are produced at a later response. IgY generally confers immunity to a patient so far as that particular infection is concerned. Our results show that serum IgM was significant low in all the groups, which indicates that the broilers used in this study were infected and adaptive immunity may have been worn off since the birds were not vaccinated against NDV and were not protected against NDV infection. Serum IgY concentrations in challenged groups were raised, which is an indicator of bird immune systems mounting resistance to the viral challenge. Antibody production is an integral part of humoral response. Plasma cells may have likely influenced the secretion of IgY antibody, if they have matured in the presence of cytokines - interferon $\gamma$. It was noted that plasma cells in the groups correlate with the level of antibody raised in each group, which indicated that a specific and appreciable antibody level against NDV was produced in the birds, though; it might not have necessary reached the threshold that could have neutralized the cytotoxic effect of the viral challenge in the birds. Perhaps, when used as adjuvant as 
recommended by Yates et al. [25] and Chinnah et al. [26] it might raise a significant titre. This observation is not at variance with that reported by other researchers [9-11, 29] who stated that the increasing presence of antibodies in naive chicken plasma binding heterologous and homologous (tissue) antigens indicates the presence of natural antibodies in poultry. Apart from age, increasing levels of natural antibodies may be related with the genetically based magnitude of specific antibody levels in the studied chicken lines. Our finding suggests that Aloe vera and A. millsoni extract may have stimulated humoral response in the test chickens, though the mechanisms of action of the extracts remain unknown. The high antibody (titre) in the vaccinated broiler chicken (control group) could be explained by the principle of active immunization against infectious disease mentioned earlier.

\section{Conclusions}

The result of the present analysis yielded a suggestion that pretreatment with the A. millsoni extract and Aloe vera improved the well-being of the birds; improved the ability to mount humoral responses against viral infection. Unlike the extract of Ganoderma and A. marginata that had no stimulating effect in the affected birds. Among the four extracts used in this study, the A. millsoni extract had a greater effect on antibody stimulation.

The authors declare no conflict of interest.

The authors wish to acknowledge the Medical Laboratory Scientists, Mr. O. O. Odewusi, Department of Medical Laboratory Sciences, Achievers University, Owo and Mr. H. Fatuade of Federal Medical Centre, Owo for their technical assistants. I also appreciate Dr. Pius Okiki, Consultant Veterinary Doctor for his expertise in handling the birds during the study.

\section{References}

1. Butcher GD, Miles RD (1993): Disease prevention in commercial poultry, University of Florida, Institute of Food and Agricultural Sciences. The document No. CIR1079, Reviewed March 2011.

2. Beisel WR (1992): History of nutritional immunology: introduction and overview. J Nutr 122 (3 Suppl): 591-596.

3. Meydani M, Lipman RD, Han SN, et al. (1998): The effect of long-term dietary supplementation with antioxidants. Ann N Y Acad Sci 854: 352-360.

4. Ojiezeh TI, Eghafona NO (2014): Nutritional and physicochemical profiles of some indigenous extracts used in alternative medicine. J. Intercult Ethnopharmacol 3: 29-36.

5. Nairn R (2004): Immunology. In: Jawetz, Melnick and Adelberg's Medical Microbiology. Geo F. Brooks, Butel JS, Morse SA (eds.). Lange Publication/McGraw-Hill, 133-135, 138-139.
6. Radoja S, Frey AB, Vukmanovic S. (2006): T-cell receptor signaling events triggering granule exocytosis. Crit. Rev Immunol 26: 265-290.

7. Vahedi G, Taghavi M, Maleki A, Habibian R (2011): The effect of aloe vera extract on humoral and cellular immune response in rabbit. African Journal of Biotechnology 10: 5225-5228.

8. Leung MY, Liu C, Zhu LF, et al. (2004): Chemical and biological characterization of a polysaccharide biological response modifier from Aloe vera L. var. chinensis (Haw.) Berg. Glycobiology 14: 501-510.

9. Pugh N, Ross SA, ElSohly MA, Pasco DS. (2001): Characterization of aloe ride, a new high molecular-weight polysaccharide from Aloe vera with potent immunostimulatory activity. J Agric Food Chem 2001; 49: 1030-1034.

10. Im SA, Oh ST, Song S, et al. (2005): Identification of optimal molecular size of modified Aloe polysaccharides with maximum immunemodulatory activity. Int Immunopharmacol 5: 271-279.

11. Boudreau MD, Beland FA (2006): An evaluation of the biological and toxicological properties of Aloe barbadensis (miller) and Aloe vera. J Environ Sci Health C Environ Carcinog Ecotoxicol Rev 24: 103-154..

12. Ang lopez J, Alis, R (2006): Indigenous uses of the native earthworm and its fatty acid profile. Paper presented at the International Symposium-Workshop on Vermi- Technology for the Developing countries (ISWVT) at Nov. 16-18, 2005, Philippine Fisheries Association, Inc. Los Bańos, Laguna, Phils. 135-144.

13. Wu JH, Xu C, Shan CY, Tan RX (2006): Antioxidant properties and PC12 cell protective effects of APS-1, a polysaccharide from Aloe vera vera var. Chinensis. Life Sci 78: 622-630.

14. Oluba MO, Onyeneke EC, Ojieh GC, et al. (2010): Hepatoprectective Protectial of Aqueous Extract of Ganoderma lucidum Against carbon tetrachloride intoxication in rats. Der Pharmacia Letter 2: 432-439.

15. Ranjna C (1991): Practical Clinical Biochemistry Method and Interpretation, Jaypee Brother Medical publishers Ltd. New Delhi, India.

16. AOAC (1980): Official methods of analysis of the Association of Analytical Chemists. 11th Edition. Washington DC, USA.

17. Mustafa YM, Muhammed AM, Aflab AA, and Mansoir-udDin-Ahmed 2010. Influence of stocking Density on immune response of Broiler against Newcastle Disease Virus. Pakistan J Life Soc Sci 8 (Suppl. 1): 7-10.

18. National Research Council (1985): Guides for the Care and Use of Laboratory Animals, National Institutes of Health, Bethesda, Md, USA.

19. Lewis SM, Bain BJ, Bates I (2000): Dacie and Lewis Practical Haematology. $9^{\text {th }}$ ed. Churchill Livingston, Edinburg 12-27.

20. Fudge AM (2000): Avian complete blood count. In: Laboratory Medicine Avian and Exotic Pets. W.B. Saunders, Philadelphia 9-18.

21. Clarke W, Dufour DR (2006): Immunoassays: Contemporary Practice in Clinical Chemistry, AACC Press, Washington, DC USA.

22. Sampedro MC, Artola RL, Murature M, et al. (2004): Mannan from Aloe saponaria inhibits tumoral cell activation and proliferation. Int Immunopharmacol 4: 411-418. 
23. Ernst E, Pittler MH, Stevinson C (2002): Complementary/ alternative medicine in dermatology: evidence-assessed efficacy of two diseases and two treatments. Am J Clin Dermatol 3: 341-348.

24. Richardson J, Smith JE, McIntyre M, et al. (2005): Aloe vera for preventing radiation-induced skin reaction: a systematic literature review. Clin Oncol (R Coll Radiol) 2005; 17: 478484.

25. Yates KM, Rosenberg LJ, Harris CK, et al. (1992): Pilot study of the effect of acemannan in cats infected with feline immunodeficiency virus. Vet Immunol Immunopathol 35: 177-189.

26. Chinnah AD, Baig MA, Tizard IR, Kemp MC (1992): Antigen dependent adjuvant activity of a polydispersed beta-(1, 4)-linked acetylated mannan (acemannan). Vaccine 2: 551557.

27. Prakash M, Balamurugan M, Parthasarathi K, et al. (2007): Anti-ulceral and anti-oxidative properties of "earthworm paste" of Lampito mauritii(Kinberg) on Rattus Norvegicus. Eur Rev Med Pharmacol Sci 11: 9-15.

28. Balamurugan M, Parthasarathi K, Cooper EL, Ranganathan LS (2007): Earthworm paste (Lampito mauritii, Kinberg) alters inflammatory, oxidative, haematological and serum biochemical indices of inflamed rat. Eur Rev Med Pharmacol Sci 11: 77-90.

29. Parmentier HK, Lammers A, Hoekman JJ, et al. (2004): Different levels of natural antibodies in chickens divergently selected for specific antibody responses. Dev Comp Immunol 28: $39-49$. 